\title{
Preliminary Study on the Teaching Reform of Economics and Management Courses Setting for Art Major
}

\author{
Xuemei Zhou \\ School of Economics and Management \\ Northeast Electric Power University \\ Jilin, China
}

\begin{abstract}
Non-art institutions have set up economics and management courses for the students of arts for many years. However, the courses are neglected and the teaching effect is not good. From the standpoint of distinguishing features and attention to practical application, this paper, based on the teaching practice and teaching experience, makes a tentative exploration on the teaching reform from the aspects of curriculum orientation, teaching content and teaching methods etc.
\end{abstract}

Keywords-teaching content; teaching methods; teaching reform

\section{INTRODUCTION}

In recent years, there has been an increase in the enrollment of students of art major, and non-art institutions also have successively set up the major of art. However, the employment rate of art graduates is not high, and the society has set new requirements for the quality of art professionals. The students of art in non-art colleges and universities, must not only grasp a solid foundation of professional knowledge, but also have some skills of management, communication and interaction. To this end, some institutions set up economics and management courses for major of art, but the teaching effect of this course is not ideal.

Based on outstanding features, we should cultivate comprehensive talents with professional knowledge, economic mind and management ability. Combining with teaching practice and teaching experience, we should make clear the orientation of the course, improve the course content, integrate the teaching resources and improve the teaching methods so as to improve the course teaching effect, and then improve the knowledge structure of art major and broaden the knowledge level of students, which is of great practical significance for improving the cultivation of art talents.

\section{COURSE RESEARCH}

Through the teaching practice of "Media Economics and Management" in near 20 classes of art major in recent two years, we found that there are some problems that should not be ignored in this course. First, it has no obvious characteristics, and only introduces some basic knowledge of economics and management, not combined with the industry; second, there is no normative setting and arrangement of curriculum structure and teaching contents. The course content, scope and profoundness are chosen and determined arbitrarily, and the teaching method is single. It is difficult to mobilize the enthusiasm of students; third, bad teaching order, low attendance in class and low enthusiasm of student for learning. The main reason is the obscure definition of the quality of economics and management for the students of art and the lack of a clear goal of curriculum for the students, which leads to an insufficient comprehension of students for the curriculum and thus affects the teaching effectiveness. Therefore, the author conducted a targeted survey to first find the existing problems and their causes, and then proposed solutions to the problems and the corresponding countermeasures.

The main object of this survey is the Art College, including four classes of Grade 14, four majors, totaling 148 students, which has a certain representation. Total 148 questionnaires were given out, for which the form of anonymous response is used, and total 125 copies were effectively replied. The questionnaire content involves learning awareness, learning attitude, learning status and teaching requirements and others, and with a wide range, it basically reflects the common problems in setting this course.

\section{A. The Survey about Basic Awareness}

For the knowledge expansion of students of Art Major in school, as shown in "Table I", most of the students think that in addition to learning of their major, they should also enrich the knowledge of other courses, mainly the general economics and management (accounting for 82.5\%), secondly the literature and history (accounting for 50\%), and finally the laws. This shows that most students subjectively have a positive desire to broaden their knowledge and a strong thirst for knowledge. This is an important prerequisite for setting up the economics and management courses 
TABLE I.

THE KNOWLEdGE SHOULd BE EXPANDED By STUDENTS

\begin{tabular}{lllll}
\hline & $\begin{array}{c}\text { Literature } \\
\text { and } \\
\text { History }\end{array}$ & $\begin{array}{c}\text { General Economics } \\
\text { and Management }\end{array}$ & Politics & Others \\
\hline $\begin{array}{l}\text { The number of students } \\
\text { (people) }\end{array}$ & 63 & 103 & 53 & 50 \\
\hline Proportion (\%) & 50 & 82.5 & 42.5 & 40 \\
\hline
\end{tabular}

During the study in college, students should focus on the cultivation of their ability. As "Table II" shows, most students recognize the importance of learning and thinking skills and professional skills (70\% and $62.5 \%$, respectively). They still have no enough awareness of the importance of communication skills (55\%). College students will face complex social work after they graduate from colleges. it is vital to cultivate the ability for how to combine our own knowledge with practice as soon as possible. Most students have already recognized this.

TABLE II. The Ability Should Be Cultivated by Students IN the Colleges ANd Universities

\begin{tabular}{lllll}
\hline & $\begin{array}{c}\text { Learning } \\
\text { and } \\
\text { Thinking } \\
\text { Skills }\end{array}$ & $\begin{array}{c}\text { Communication } \\
\text { Skills }\end{array}$ & $\begin{array}{c}\text { Professional } \\
\text { Skills }\end{array}$ & Others \\
\hline $\begin{array}{l}\text { The number of students } \\
\text { (people) }\end{array}$ & 88 & 69 & 78 & 9 \\
\hline Proportion $(\%)$ & 70 & 55 & 62.5 & 7.5 \\
\hline
\end{tabular}

In the survey on the necessity of setting up economics and management courses for art major. 90\% of students think it is necessary to set up an economics and management course. From this point, the setting of this course meets the requirements of students.

For the survey on the learning objectives, as shown in "Table III", the students' awareness of learning objectives mainly include the following aspects: first, to broaden their knowledge scope $(60 \%)$; second, to meet the examination $(50 \%)$. only $35 \%$ of students think it will be used in the future. These data objectively reflect the reasons that students do not attach importance to this course, that is, they think they have to broaden their knowledge scope, but it may not be used in the future, and they lean the course only to meet the examination.

TABLE III. LEARNING OBJECTIVES

\begin{tabular}{lllll}
\hline & $\begin{array}{c}\text { To Broaden } \\
\text { the Knowledge } \\
\text { Scope }\end{array}$ & $\begin{array}{c}\text { Used in } \\
\text { the Future }\end{array}$ & $\begin{array}{c}\text { Deal with } \\
\text { the Exams }\end{array}$ & Others \\
\hline $\begin{array}{l}\text { The number of students } \\
\text { (people) }\end{array}$ & 75 & 44 & 63 & 3 \\
\hline Proportion $(\%)$ & 60 & 35 & 50 & 2.5 \\
\hline
\end{tabular}

\section{B. Survey of Study Status}

When asked whether there was any difficulty in learning this course, 78 students $(62.5 \%)$ answered they had difficulty; for the setting date of this course, $57.5 \%$ of the students thought that it should be set in the third grade (in line with the new training plan), and $30 \%$ of the students thought it should be at the second grade. For the reasons why students feel difficult in learning economics and management courses, as shown in "Table IV", the conditions are rather complicated. Of them, $60 \%$ have difficulty in learning due to lack of subjective awareness and lack of hard study, and 35\% due to lack of interest; $27.5 \%$ think it has conflict with reviewing for postgraduate entrance exams, and 5\% think they don't like the course teacher; other reasons accounted for $17.5 \%$.

TABLE IV. The Reasons Why Students Feel Difficult in Learning This Course

\begin{tabular}{llllll}
\hline & $\begin{array}{c}\text { Lack of } \\
\text { Awarene } \\
\text { ss }\end{array}$ & $\begin{array}{c}\text { Don't Like } \\
\text { Teacher }\end{array}$ & $\begin{array}{c}\text { Conflict with } \\
\text { Reviewing } \\
\text { for Postgraduate } \\
\text { Entrance Exams }\end{array}$ & $\begin{array}{c}\text { Lack of } \\
\text { Interest }\end{array}$ & Others \\
\hline $\begin{array}{l}\text { The number } \\
\text { students (people) }\end{array}$ & 76 & 6 & 34 & 43 & 22 \\
\hline Proportion (\%) & 61 & 5 & 27.5 & 35 & 17.5 \\
\hline
\end{tabular}

The survey on students' learning status shows that:

The learning of economics and management is worried among the students of art major, and most of them feel difficult in learning this course.

Schools and teachers are not meticulous and solid when they guide students to correctly understand and treat economics and management courses. As a result, a large number of students $(61 \%)$ have insufficient awareness. Most students think it is necessary to start the course, but in fact they have little interest in the course (35\%).

Some students think that this course conflicts with the review for postgraduate entrance exams. Since this course 
was set up in the second semester of the third grade, it is the key period for the review for postgraduate entrance exams, so we can consider opening it in the first semester of the third grade.

\section{Survey of Teaching Requirements}

The response for teacher's classroom teaching is as shown in "Table V".

TABLE V. Popular Teachers SHOUld HaVe

\begin{tabular}{llllll}
\hline & & $\begin{array}{l}\text { Strict and } \\
\text { Principled }\end{array}$ & $\begin{array}{c}\text { Large and Rich Lecture } \\
\text { Information }\end{array}$ & $\begin{array}{c}\text { Frequently Organize } \\
\text { Discussions and Inspire } \\
\text { Students' Thinking }\end{array}$ & $\begin{array}{l}\text { Not Bewilder Students } \\
\text { in Exams }\end{array}$ \\
\hline $\begin{array}{l}\text { The number } \\
\text { students (people) }\end{array}$ & 1 & 119 & 34 & 125 \\
\hline Proportion (\%) & 0.8 & 95 & 27.5 & 100 \\
\hline
\end{tabular}

Almost all students like the teachers who can give them large lecture information and make them relatively easily pass the exams (up to $95 \%$ and $100 \%$ ), but it should not be overlooked that $100 \%$ of students judge their teachers based on their exams, and hardly anyone likes the teachers who are strict and principled. This result reflects that most of the students can objectively and reasonably evaluate classroom teaching, expect good classroom teaching and good benefits; it also reflects most students have the strict requirements that the vast majority of students are weak self-discipline and fear teachers' strict requirement, which is an extremely unhealthy learning psychology and must be corrected.

Among the suggestions and requirements on economics and management courses, the following three points are more representative. First, try to schedule the course in the first semester of the third grade of colleges. At this time, the students already have the relevant preparatory knowledge of learning economics and management courses, the learning task for basic courses and specialized courses of each major is not particularly heavy, and it is just staggered with the key period of review for postgraduate entrance exams; second, we should pay attention to the theory with practice in the classroom teaching, so that students can apply their knowledge; third, teachers should explain profound theories in simple language in the class, making students easily understand. Because of the professional characteristics, the intensity of study, the way of thinking and the lack of basic knowledge of economy, the students of art major must have some special requirements in the study of economics and management courses. Whether these requirements can be adequately met is also an important factor that affects the effectiveness of this course.

\section{THE REFORM OF THE COURSE TEACHING}

\section{A. Make Clear the Course Positioning}

In order to improve the quality of the students of art in economics and management, we should highlight the cultivation of students in management, communication and coordination skills, make a close combination of professional skills and economic management knowledge, and within a limited time, make students master the basic knowledge of economics and management that is closely connected with the exertion of technical expertise, and make them have both professional knowledge and management ability, so as to adapt to the needs of the market economy [1].
Guide and educate students to make them fully understand the necessity and importance of opening the courses of economics and management. Relevant departments and teachers in schools should first conduct indepth guidance and education in terms of their learning attitudes and learning objectives so that the students of engineering can truly recognize that the setting of economics and management courses is conducive to the optimization of their knowledge structure, the development of their ability and the improvement of their overall quality.

\section{B. Integrate the Teaching Content}

Based on the principle of "focusing on thinking, methods and application", we should carefully select the contents of the teaching, mainly emphasizing the practicality, and take the technical economics as the core for studying the economic evaluation theories and methods of various decision-making plans, to build a reasonable course structure that makes a close combination with economics and management theory knowledge and the specialty of media industry and give a comprehensive and systematic introduction of relevant basic concepts, theories and methods[2]. We should make a calculation, analysis, comparison and evaluation on the economic effects of various decision-making programs when giving a key explanation. At the same time, we should give a full and systematic introduction of the reform and development of China's media industry and culture industry, avoiding the principle of "generality, emptiness and boringness". We also should organizes and selects the lectures, which mainly include three parts, such as the basic knowledge of management, the introduction of technical economics, and the introduction of media industry.

Based on the objective of cultivating compound talents, from the practical point of view, we can add the contents such as communication skills of managers, art of leadership and ways of improving work performance, and explain them in a form of topics. These contents are very important for the students to take up the management posts and even the leadership positions in the future.

\section{Improve the Teaching Methods}

In the previous teaching, we often emphasize the theory but ignore the application, so we must make some improvements on the teaching methods. First, we should strengthen case teaching, introduce examples to make analysis, and combine theory with practice. Second, if any 
applicable for class time, we should take some class time for students to do a course design. We can introduce some practical projects, and on the basis of simplification, ask students to analyze the feasibility of some projects and to evaluate the economic benefits of such projects, making them experience how to use the economic evaluation method in the practical projects. We can divide students into several groups, making them complete the task in a group, which can also cultivate students' teamwork spirit. Third, we should arrange the necessary discussions, and make students carry out a full discussion, interaction and role playing when giving lecture of a topic, in which students can fully pay attention to the class and experience the skills and charm of management [3].

We should help students improve their learning methods, change their way of thinking, so as to make them adapt to the study of economics and management courses. The students of art major generally feel difficult to learn economics and management courses, which are mainly led by inadequate awareness and improper attitude but more importantly by improper learning methods, and by some problems of ways of thinking. They often have no enough logical thinking skills and case analysis skills necessary for studying economics and management courses. Teachers should take the initiative to understand the learning methods and learning conditions of students, and provide targeted guidance and training so that students can adapt to the learning of this course as soon as possible.

Teachers should constantly reform the class teaching methods and the curriculum assessment methods, and according to the characteristics of the curriculum and the actual conditions of students, effectively improve the teaching effectiveness [4]. In the class teaching, teachers should not only pay attention to the introduction of economics and management theory, but also pay attention to the analysis and discussion of economic phenomena and management problems. The content of class teaching should be full and rich, and the classroom atmosphere should be positive and lively. Teachers should try to attract students to take the initiative to adapt to and participate in class teaching activities, so that students not only improve their basic theoretical qualities, but also avoid the disconnection of the theory and the reality. In the assessment of the course, we should not focus solely on the check of the theory of economics and management, but we should also pay attention to the analysis and solution of practical problems; and the assessment methods can be appropriately diversified.

\section{CONCLUSION}

This innovative point of education reform is to highlight the characteristics, focus on the practical application, inspire the interest of art students in learning economics and management, make students improve their ability of dealing with actual management problems in combination with their major, and further make a overall scientific dynamic optimization of the teaching of economics and management courses in curriculum structure, content arrangement, teaching methods and so on, which will have an important practical significance for the cultivation of students in their practical ability and their thinking ability of economics and management, so that we will improve the teaching quality and the position of this course.

\section{REFERENCES}

[1] Ma Hongmin. Exploration on Curriculum Construction and Talen Cultivation of Art Management Major in Non-art Universities [J] Going Abroad and Employment, 2011 (12): $78 \sim 79$

[2] Jin Guilin. Research on Multi-Level Practice Teaching System of Art Major [J]. Art Technology, 2017 (10): $32 \sim 33$

[3] Zhang Yang. Research on the Application of Situational Teaching in Art Management Courses [J]. Art Education, 2015 (8): $147 \sim 148$

[4] Zhang Yang. Analysis on the Teaching Way Changes Of Art Management Curriculum [J]. Popular Arts, 2014 (2): 237 